\title{
EFL Teachers' Beliefs and Practices of Teaching Pronunciation in a Vietnamese Setting
}

\author{
Diem Phuong Thi Tran", Huan Buu Nguyen", * \\ ${ }^{1}$ Aston English Language Center, Can Tho City, Vietnam \\ ${ }^{2}$ School of Foreign Languages, Can Tho University, Vietnam
}

Received August 21, 2020; Revised November 13, 2020; Accepted November 29, 2020

\begin{abstract}
Cite This Paper in the following Citation Styles
(a): [1] Diem Phuong Thi Tran, Huan Buu Nguyen, "EFL Teachers' Beliefs and Practices of Teaching Pronunciation in a Vietnamese Setting," Universal Journal of Educational Research, Vol. 8, No. 12, pp. 7022 - 7035, 2020. DOI: 10.13189/ujer.2020.081270.
\end{abstract}

(b): Diem Phuong Thi Tran, Huan Buu Nguyen (2020). EFL Teachers' Beliefs and Practices of Teaching Pronunciation in a Vietnamese Setting. Universal Journal of Educational Research, 8(12), 7022 - 7035. DOI: 10.13189/ujer.2020.081270.

Copyright $\odot 2020$ by authors, all rights reserved. Authors agree that this article remains permanently open access under the terms of the Creative Commons Attribution License 4.0 International License

\begin{abstract}
A plethora of research has witnessed the relationship between beliefs and practices that influence how language teachers make their own decisions to improve their instruction and enhance student learning at tertiary education. In particular, to date, there has been a growing interest in pronunciation teaching of English as a foreign or second language. However, research into beliefs and practices of foreign language learning, namely English, with regard to pronunciation within the Vietnamese context is still scarce. This current study, therefore, is aimed to explore what beliefs teacher hold and how they teach pronunciation in a Vietnamese context. This paper draws on data collected as part of a larger study including questionnaires, interviews, and observations over a fifteen-week semester of an EFL pronunciation course. The focus of this paper is on the data from the questionnaire and observations. The study was conducted with seventy teachers at an English language center in the Mekong Delta, Vietnam. The findings indicate that the teachers had positive beliefs about teaching pronunciation and that the teachers integrated pronunciation in their English classes with specific focus on intelligibility. The findings further extend the literature on pronunciation teaching practices by providing insights into how contextual factors mediate teachers' existing beliefs and actual happenings that inform their future practices by reflecting on their professional development and learning regarding pronunciation as crucial constituent of learners' communicative competence. The paper concludes by discussing pedagogical implications for teachers, school administrators for the
\end{abstract}

sake of better pronunciation instruction.

Keywords Teachers' Beliefs, Pronunciation Teaching, Intelligibility

\section{Introduction}

Since English is widely held as an international language that help people communicate in different aspects of life, it is necessary for Vietnamese learners to obtain intelligible communication in English to keep up with the increased demands of academic and job markets in the globalized world, as highlighted in the National Foreign Language Project (VNFLP) launched by the Ministry of Education and Training. To obtain the communicative competence, pronunciation plays a crucial role in the real-life communication process which reflects speakers' identities [1]. Effective pronunciation teaching will contribute to facilitating learners' academic achievements and potential job opportunities. However, there has been little discussion about teachers' beliefs and practices in relation to teaching pronunciation in Vietnam. In particular, it was found that in a study of common pronunciation problems of Vietnamese learners of English by [2], pronunciation challenges Vietnamese learners as only a few have intelligible English pronunciation in direct communication with foreigners. This could be explained in ways that English sound system has sounds foreign to Vietnamese speakers, and that the 
English ending sounds were pronounced differently from those by Vietnamese learners or speakers. These challenges may somehow hinder learners from successful communication or communicative competence. This paper, therefore, examines teachers' beliefs and practices in pronunciation classrooms within the Vietnamese context of teaching and learning.

\section{Literature review}

\subsection{Teachers' Beliefs}

Teachers' beliefs have been discussed in several ways in the literature, including teaching and learning English as a foreign language. The term teachers' beliefs is integral in helping teachers make their instructional decisions in their classroom practices and enhance learners learning [3]. Pajares claims that beliefs are "an individual's judgements of the truth or falsity of a proposition" (p.316). Thus, beliefs function as a filter to reflect individual teachers' prior expectations and form their actions. In particular, there is evidence that there is an increasing recognition of the significance of teacher beliefs about change in teaching and learning of foreign languages [4]. In other words, teachers' beliefs contribute to effective teaching. However, there have not been any studies that have examined teacher's beliefs and practices regarding teaching pronunciation within the Vietnamese context of teaching and learning English as a foreign language. This paper, therefore, explores teachers' beliefs and their practices of pronunciation teaching in a Vietnamese setting.

\subsection{Pronunciation teaching}

Pronunciation is a process of producing sounds of a language that makes communication effective and as a result, learners become aware of such impact while using English [5]. Canagarajah states that "pronunciation is perhaps the linguistic most open to judgment. As a surface structure, phenomenon that is most noticeable, one's accent easily evokes people's biases. For the same reason, pronunciation has been the most prescriptively taught aspect of language instruction" (p.365). In the same vein, pronunciation is the way in which a word is pronounced and used for making meanings [6] and [7]. It includes segments such as consonants and vowels of language, supra-segmental features like stress, rhythm, intonation and how the voice is described (voice quality). To put it simply, pronunciation is viewed as a part of communication process that addresses how to correct sounds in order to express the meanings in different contexts.

\section{The importance of English pronunciation instruction}

Hismanoglu states that pronunciation instruction plays an important role in communicative competence supported by the speaker and the listener's understanding which requires a comprehensible pronunciation skill. Learners' pronunciation capacity has an influence on their overall language ability. Hence, effective pronunciation provides positive impression, understanding and effective communication. Mastering of grammatical structures and having a wide range of vocabulary are essential elements of language, but they can be useless if the speakers pronounce [6].

In order to become proficient in pronunciation, learners are encouraged to produce the accuracy of phonemes, intonation, rhythm, stress, connected speech and other things [8]. It should be noticed that pronunciation instruction is a crucial and fundamental component of each oral communication classroom [9]. Therefore, it is impossible to overlook the significance of pronunciation pedagogy. Teaching pronunciation helps the speakers understand and enhance their ability to communicate [7]. Thomson and Derwing [10] also state pronunciation instruction has brought positive results which lead to improve the target of L2 production. Moreover, pronunciation instruction is beneficial to learners because they enhance their self-awareness, improve listening skills, arouse their motivation and establish a life-long study [11].

\section{The targets of teaching English pronunciation}

According to [12], English pronunciation instruction has two different goals: nativeness and intelligibility. While nativeness goal is to help speakers acquire a native-like accent, intelligibility focuses on the extent to which the speakers' intended utterance is understood by a listener [13]. Furthermore, the reducing and moving a second language (L2) accent are teachers' criteria or judgments of learners' speech [12], [14]. Similarly, most of learners responded that they consider native accents pronunciation as a benchmark of academic achievement [15]. As an advocate of this view, [16] stress that the removal of native models from pronunciation class could make pronunciation poor quality. However, the native-like goal of teaching pronunciation seems to be difficult for most English adult speakers because of several aspects such as age, sociocultural factors, and the like [17]. Hence, nativeness principle can be a main objective, but it cannot be the target for teachers to improve their learners' pronunciation and confidence.

On the other hand, the intelligibility principle is realistic and gives desirable outcomes. The intelligibility principle is defined as learners' understanding of L2 speech [13]. Recently, the intelligibility goal of pronunciation teaching is dominant the native-like accent and more realistic target for L2 learners [12], [13]. Thornbury [18] claims that intelligibility in English pronunciation is more significant than nativeness. He also suggests that teachers should increase learners' awareness of intelligible and receptive aspects. Likewise, it is interesting to note that speakers will 
be successful in communicative competence if they are comfortably intelligible to what others can comprehend what they say and they understand what others speak to them [7]. In the same vein, learners' perceptions and views on English pronunciation teaching in Finland have been considered [19]. The result revealed that intelligible speech was the primary goal and a native-like accent was not mentioned as their aspirations in English pronunciation. A study of five experience English teachers demonstrates that teachers needed to support learners to achieve intelligibility in pronunciation to comprehend listeners from variety language backgrounds [20].

In spite of the current dominance of intelligibility as the prime goal of pronunciation instruction, both intelligibility and nativeness continually influence both pronunciation patterns or models indicated in the foreign/second language curriculum and pronunciation acquisition of L2 learners.

\section{Approaches in teaching pronunciation}

Celce-Murcia, Brinton \& Goodwin [21] indicate that intuitive-imitative approach, analytic-linguistic approach and integrative approach are the three pronunciation instructional approaches.

With regard to intuitive-imitative approach, L2 learners imitate and listen to the sounds and rhythms of a foreign language without interference of explicit instruction. Some recommended tools for this approach include audiotapes, websites, videos, computer-based programs [22], whereas analytic-linguistic approach provides learners with explicit intervention of pronunciation pedagogy like phonetic alphabets, articulatory descriptions, and vocal charts. The explicit data can be presented in different interactive speech software and websites [23]. In the integrative approach, teachers point out that the best way to teach pronunciation is the integration of skills into language use, as perceived as beneficial in EFL classrooms by [24]. First of all, learners have countless opportunities to interact with authentic and meaningful lessons, instead of learning pronunciation in isolation. Second, the incorporation of multiple skills supports learners' language learning process which focuses on a positive and collaborative environment and lateral thinking skills. Third, learners can develop academic subjects and interaction. Moreover, a study by [25] asserts that "integral teaching helps to overcome three primary problems in pronunciation teaching: insufficient time in class, miss-targeting of lessons to intermediate and advanced students, and lack of awareness by students and teachers of the connection between pronunciation teaching and effective aural-oral communication" (p.99). Therefore, it is used as the second theoretical background for this study in teaching pronunciation.

\section{Techniques in teaching pronunciation}

Pronunciation instruction is a fundamental component in oral communication. Traditionally, EFL teachers have taken advantages of the phonetic alphabets and activities such as repetition drills, detailed description of the articulatory system, focused on production tasks (e.g., minimal pair drills, reading aloud, contextualized sentence practices, recognition and discrimination tasks, visual aids and recordings [21]. There is no the best technique for teachers because of various target learners and different contexts. Some techniques are beneficial to some learners, but other learners are not easily advantageous from pronunciation techniques that are useful for someone. It depends on the learners and teachers' needs to determine which techniques are appropriate for them. Since communicative approach has dominated the foreign language teaching. Therefore, modern techniques are being developed to complement the English pronunciation pedagogy. There are recently immense genres of technology equipment and applications utilized in education. They include computers, LCD panels, projectors, website development, presentation software (Power Point), digital cameras, internet, e-mail, scanners, distance education/ video conferencing system, assistive technologies, databases, graphics programs, electronic references (e.g., Encarta, World Book), word processing, spreadsheets, discussion groups/ list servers, instructional software (tutorials, drills and practice), instructional methods for integrating technology, and hypermedia [26].

\subsection{Teachers' Beliefs and Practices in Teaching Pronunciation}

Recently, increased attention has focused on teachers' beliefs and practices in teaching pronunciation at several countries, namely Australia [27], in USA [28] and [29], in Europe [22], in Asia [30], [31], [32].

Practitioners are likely to lack awareness or become reluctant to teach pronunciation. For example, the findings from a study by [27] who interviewed eight teachers in Australia, indicated that teachers were unwilling to teach pronunciation because of their lack of encouragement to teach pronunciation based on the set curricula, insufficient knowledge of assessing learners' pronunciation, and feeling uncomfortable while monitoring their learners' practices. The call for more education opportunities was indicated in the literature that English teachers were not given sufficient pronunciation training and strived to improve professional development in this area [33], [29]. [29] as an example, demonstrated that teachers wish to have more pronunciation training to acknowledge linguistic diversity. Sixteen NNESTs were interviewed in Hong Kong and it was found that teachers are likely to feel unsure in their classrooms, possibly caused by inadequate teacher education and particular institutional and sociocultural context [30]. This view was supported by [32]. The teachers had the lack of initial training and professional learning opportunities in teaching pronunciation. 
A considerable amount of literature considered the preferred approaches and techniques employed by teachers regarding pronunciation instruction. Chiu [31], for example, interviewed six participants including three NNESTs and three NESTs in Taiwan. The findings demonstrated the NESTs preferred intuitive-imitative approach when teaching pronunciation while the NNESTs tended to use more linguistic-analytic approach, but both emphasized their teaching on the segmental levels. In addition, [22] surveyed 103 EFL teachers in North Cyprus to examine the preferred approaches and techniques when teaching pronunciation. The survey indicated that teachers tended to use intuitive-imitative approach, and dictation, reading aloud, and dialogues were the three favored traditional techniques in teaching pronunciation. It could be concluded teachers seemed to be in favor of traditional approaches in teaching pronunciation, even though these approaches were criticized without innovation and variety in pedagogical pronunciation.

Borg [34] states that teachers' practices are an expression of their beliefs. Beliefs have a potential influence on the pedagogy making decisions. Therefore, a growing body of research into educators' beliefs and how their cognition linked to their actual practices regarding grammar [35] and [36]; reading comprehension [37]; listening [38] and pronunciation instructions in different contexts including Australia [27], Taiwan [31], Canada [33], Brazil [28], Iran [39], Europe [40], [41], [22] , USA [29] and Vietnam [32] to have a solid foundation for further explanation on pronunciation.

A growing body of literature investigated which goals of teaching pronunciation should be considered and which features of pronunciation should be taught. Sifakis and Sougari [40], for instance, explored the beliefs regarding the significance of native speakers' accents and their roles in pronunciation norms and models in Greece. The results showed that the standards English of native-speakers as models were dominantly important in primary level. Other relevant findings were found that accentedness was an integral goal in English language learning and teaching by most of respondents. They lacked the ability and self-perceived efficacy in teaching pronunciation and were convinced that NESTs would be better to teach pronunciation because learners could access with standard pronunciation. Conversely, in the study of [28] who examined the beliefs and practices of Brazilian EFL teachers, an absolutely high proportion of teachers had generously positive attitudes towards in teaching pronunciation. Numerous studies stated that intelligible speech was a dominant goal in teaching pronunciation than accentedness [30], [29], [12], and [32].

Teachers tended to concentrate less on suprasegmental features and more on segmental ones though they had a generously high degree of importance in teaching suprasegments for the intelligible goal of oral communication [31], [33], [32]. Foote, Holtby and
Derwing [33] conclude that the degree of teachers' beliefs about teaching pronunciation was insignificant differences, an awareness of the importance of suprasegmental features had a sharply increase, but the teachers seemed to be more segmental in actual practices. To support this view, there was a triangulation of data to scrutinize the teachers' cognitions and the practices of language teachers conducted by [42]. Based on the results, an unsurprising finding from both quantitative and qualitative data was that teachers had a tendency to take precedence over individual segments and transcription exercises, but neglected the suprasegmental aspects as stress and intonation which do not differ the findings with one of previous study in Saudi Arabia [43]. In the same vein, [32] reveal that vowels and consonants were much more focused than prosody. It was a contradictory with teachers' goal of teaching pronunciation since the vast majority of teachers favored in the intelligibility principle in teaching pronunciation than nativeness.

Teaching pronunciation mastery is influenced by several factors which has addressed in some studies regarding teachers' beliefs and practices in teaching pronunciation [e.g., 8, 31]. According to [30], the majority of teachers in Hong Kong reported that they were of time constraints, pronunciation resource restrictions, heavily exam-oriented cultures and teacher education inadequacy. Hence, they mainly paid attention to teach grammar and vocabulary knowledge in their actual classes. In the same vein, a study by [44] in Cyprus investigated teachers' cognitions, challenges and practices of different age groups varied from 23 to 61 of EFL teachers with regard to teaching pronunciation. As the results, the oldest group responded different cognitions with the younger groups (e.g., they believed that pronunciation skills were less important than other teaching areas). The challenges were listed in teaching pronunciation such as time constraints, insufficient training, lack of pronunciation activities and resources. It was consistent with [45]. The findings were that Japanese EFL teachers were inadequate time and lacked of pronunciation training courses.

Although most above-mentioned studies examine teachers' beliefs and practices in teaching pronunciation, little research has been undertaken to look into how teachers believe in what to do with pronunciation instruction at foreign language centers within the Vietnamese context. This study, therefore, fills the gap.

\section{The study}

\subsection{Design and Participants}

This study examines an aspect of a wider study that utilized a mixed-methods design to identify teachers' beliefs and their practices of pronunciation teaching. According to [46], a mixed methods study allows for 
countless opportunities to corroborate findings across methods, and as a result of such combination this could enhance the validity of the study.

Questionnaires were used to assemble data about participants' background information and their beliefs regarding teaching English pronunciation. In addition, to shed more light on teachers' beliefs, a qualitative method is recommended [47]. Qualitative data from observations were conducted to deepen understandings of the actual happenings of teachers' pronunciation practices.

Seventy EFL teachers (seven males and sixty-three females) from a private English language center in the Mekong Delta, Vietnam participated in the study. They were of various teaching experiences ranging from less than 2 years $(\mathrm{n}=15)$ made up for $21.4 \%, 2$ to 5 years $(\mathrm{n}=35)$ accounted for $50 \%, 6$ to 10 years $(\mathrm{n}=18)$ occupied $25.7 \%$ and more than 10 years $(n=2)$ constituted $2.9 \%$. Their participation was voluntary when they were asked to respond to the questionnaire. After completing the questionnaires, six teachers whose teaching experiences were from five years were observed according to their willingness and predetermined schedule. The time for individual observations was approximately a forty-five-minute period.

\subsection{Data Analysis}

\subsubsection{Analysis of the questionnaires}

The questionnaires were analyzed using the SPSS, version 20. First the Scale test was run to check the reliability of the questionnaires collected from the participants. The result showed that the reliability coefficient of the questionnaires was confirmed $(\alpha=.80)$, as indicated at a high level $(\alpha=.70)$ [48]. Next, the Descriptive Statistic Test and One Sample t-Test were computed to examine teachers' beliefs and their practices regarding teaching pronunciation.

\subsubsection{Analysis of the classroom observations}

For qualitative data from observation, the researcher was of a general description at the beginning. The participants became more concrete on the essential aspects of the research questions. From the observation checklist, the question types were grouped. The researcher, then described the scenario as examples of categories teachers used in their classrooms.

\section{Findings}

This section presents the findings of the study regarding teachers' beliefs and practices about pronunciation instruction in EFL classroom practices.

\subsection{Teachers' beliefs about teaching pronunciation}

4.1.1. Findings from questionnaires

\section{a Beliefs regarding teaching pronunciation}

Of 70 surveyed teachers, 67 teachers $(95.7 \%)$ valued pronunciation as effectively communicative skill, as presented in Table 1.

Table 1. Percentages of teachers' beliefs about teaching pronunciation

\begin{tabular}{|c|c|c|c|c|c|c|}
\hline \multicolumn{7}{|l|}{ Frequencies $(\mathbf{F})$} \\
\hline \multirow[t]{2}{*}{ Items } & \multicolumn{2}{|c|}{$\begin{array}{c}\text { Disagree \& } \\
\text { strongly } \\
\text { disagree }\end{array}$} & \multicolumn{2}{|c|}{ Neutral } & \multicolumn{2}{|c|}{$\begin{array}{c}\text { Agree \& } \\
\text { Strongly } \\
\text { agree }\end{array}$} \\
\hline & $\mathbf{F}$ & $\%$ & $\mathbf{F}$ & $\%$ & $\mathbf{F}$ & $\%$ \\
\hline I think teaching pronunciation does not influence the learners' output. & 64 & 94.1 & 0 & 0 & 6 & 8.6 \\
\hline I think teaching pronunciation is a difficult task. & 12 & 17.2 & 12 & 17.1 & 46 & 65.8 \\
\hline I think a heavy accent usually makes learners incomprehensible. & 13 & 18.6 & 17 & 24.3 & 40 & 57.1 \\
\hline $\begin{array}{l}\text { I think pronunciation taught by a native speaker can be a good way to enhance } \\
\text { learners' listening ability. }\end{array}$ & 3 & 4.3 & 9 & 12.9 & 58 & 82.9 \\
\hline $\begin{array}{l}\text { I think pronunciation teaching allows learners to communicate with each other } \\
\text { effectively. }\end{array}$ & 1 & 1.4 & 2 & 2.9 & 67 & 95.7 \\
\hline I think mastering native-like pronunciation can be limited by age relation. & 19 & 27.1 & 22 & 31.4 & 29 & 41.4 \\
\hline I think motivated learners can learn pronunciation better. & 2 & 2.8 & 8 & 11.4 & 60 & 85.8 \\
\hline $\begin{array}{l}\text { I think pronunciation teaching is not seen as necessary, as learners tend to acquire } \\
\text { this practice once frequently exposed to it. }\end{array}$ & 58 & 82.8 & 5 & 7.1 & 7 & 10 \\
\hline $\begin{array}{l}\text { I think some teachers do not want to change their English pronunciation in order } \\
\text { to maintain their L1 identity. }\end{array}$ & 40 & 57.1 & 19 & 27.1 & 11 & 15.8 \\
\hline $\begin{array}{l}\text { I think pronunciation is best learned by exposing to it while living in English } \\
\text { speaking country. }\end{array}$ & 21 & 30 & 15 & 21.4 & 34 & 48.5 \\
\hline $\begin{array}{l}\text { I think pronunciation is best learned through thorough practice, instead of rules } \\
\text { or theoretical explanations. }\end{array}$ & 31 & 44.3 & 17 & 24.3 & 22 & 31.5 \\
\hline I think most learners are afraid of being corrected while learning pronunciation. & 12 & 17.1 & 14 & 20 & 44 & 62.8 \\
\hline I think it is difficult to teach pronunciation to elementary learners. & 56 & 80 & 10 & 14.3 & 4 & 5.7 \\
\hline I think I do not love teaching pronunciation. & 54 & 77.1 & 10 & 14.3 & 6 & 8.5 \\
\hline
\end{tabular}


Table 1 shows that almost all of the teachers (95.7 \%) believed that pronunciation instruction could allow learners to communicate with others in English $(\mathrm{n}=67)$. A smaller but still large percentage $(85.8 \%)$ thought that learners could learn better if they were highly motivated. $82.9 \%$ believed that native speakers played a crucial role in enhancing learners' listening ability. However, about two-thirds of participants (62.8\%) agreed that learners were concerned about being corrected by the teacher while learning pronunciation.

Of the seventy participants who responded to the statement, sixty-four disagreed that pronunciation instruction did not affect to learners' output. A larger number of participants $(82.8 \%)$ highly evaluated the role of pronunciation instruction. The majority of those who disagreed with the belief that frequent exposure to good input is sufficient for learners to acquire pronunciation $(n=58)$. Over half of those surveyed $(57.1 \%)$ indicated that a heavy accent usually made learners incomprehensible, whereas $24.3 \%$ were neutral or unsure. A similar percentage $(51.7 \%)$ disagreed that some people resisted changing their pronunciation so as to sustain their L1 identity $(\mathrm{n}=40), 15.8 \%$ agreed with this statement $(\mathrm{n}=11)$.

Though most of participants (77.1\%) enjoyed teaching pronunciation $(n=54)$, most of them agreed $(65.8 \%)$ that it was a difficult task $(n=46)$. Moreover, $(80 \%)$ disagreed that it was hard to teach pronunciation at the elementary level.

\section{$b \quad$ The level of training and confidence in teaching pronunciation}

When the teachers were asked to indicate their level of agreement for their confidence and training in teaching pronunciation, nearly half of the respondents $(44.3 \%)$ agreed that they were pleasured with their own English pronunciation. The rest ones indicated the disagreement and neutral about this statement were $25.7 \%$ and $30 \%$ respectively. Besides that, the proportion of those who were confident to teach segments was $67.2 \%$, higher than teaching supra-segmental features $20.1 \%$. Fever were comfortable teaching prosodic features $(\mathrm{n}=7)$. The high percentage of participants expressed a desire for more training in pronunciation instruction $(65.7 \%)$. Only four of them did not want more training as shown in Table 2.

Table 2. Percentages of teachers' beliefs in teaching pronunciation regarding level of training and confidence

\begin{tabular}{ccccccc}
\hline & \multicolumn{2}{c}{ SD \&D } & N & & A \&SA \\
\cline { 2 - 7 } Items & $\mathbf{F}$ & $\begin{array}{c}\mathbf{P} \\
(\boldsymbol{\%})\end{array}$ & $\mathbf{F}$ & $\begin{array}{c}\mathbf{P} \\
(\boldsymbol{\%})\end{array}$ & $\mathbf{F}$ & $\begin{array}{c}\mathbf{P} \\
(\boldsymbol{\%})\end{array}$ \\
\hline $\begin{array}{l}\text { I think I am completely comfortable teaching supra-segmental } \\
\text { features (e.g. syllable structure, stress, rhythm \& intonation). }\end{array}$ & 12 & 17.2 & 25 & 35.7 & 33 & 47.1 \\
\hline $\begin{array}{l}\text { I think I am completely comfortable teaching segmental } \\
\text { features (e.g. individual sounds, such as } / \mathrm{p}, / \mathrm{s} /, / \mathrm{i} /, / \mathrm{i} / /, \ldots) .\end{array}$ & 7 & 10 & 16 & 22.9 & 47 & 67.2 \\
\hline I think I am satisfied with my own English pronunciation & 18 & 25.7 & 21 & 30 & 31 & 44.3 \\
\hline I think I need further training in pronunciation teaching. & 4 & 5.7 & 20 & 28.6 & 46 & 65.7 \\
\hline
\end{tabular}

c The most serious pronunciation problems experienced by learners

With regard to the main pronunciation problems experienced by the participants' learners, two main genres are identified as segments and supra-segments.Table 3 lists the features that were challenges for learners.

Table 3. Most difficult features experienced by learners

\begin{tabular}{|c|c|c|c|}
\hline & Pronunciation Problems & $\mathrm{F}$ & $\mathrm{P}(\%)$ \\
\hline 1 & Stress (e.g. perfect= PERfect, eleven $=$ eLEven $)$ & 33 & 47.1 \\
\hline 2 & Rhythm (e.g. CAT, EAT, FISH takes roughly the same time to say as the CATS will EAT the FISH) & 32 & 45.7 \\
\hline 3 & Intonation (e.g. I have a new house (falling intonation) and I have a new house? (rising intonation)) & 46 & 65.7 \\
\hline 4 & Syllable (e.g. pencil has two syllables: /pens1/) & 18 & 25.7 \\
\hline 5 & Vowel sounds (e.g. /i/,/i:/...) & 18 & 25.7 \\
\hline 6 & Consonant sounds (e.g. $/ \mathrm{t} /, / \mathrm{k} /, / \mathrm{s} / \ldots)$ & 28 & 40 \\
\hline 7 & Minimal pairs in general (e.g. cut and cat, not and note, ball and tall) & 25 & 35.7 \\
\hline 8 & -ed and/ or - s endings & 47 & 67.1 \\
\hline 9 & The sounds of th $(/ \theta /$ and $/ \delta /)$ & 56 & 80 \\
\hline
\end{tabular}


Table 3 shows that the most frequently reported $(\mathrm{n}=56)$ refers to segments, especially with the sounds of "th" $(/ \theta /$ and $/ \delta /)$, followed by suffixes $-e d$ and $-s(\mathrm{n}=47)$. Another teachers mentioned that their learners found difficult in learning consonant sounds $(n=28)$, minimal pairs $(n=25)$, syllable $(n=18)$ and vowel sounds $(n=18)$. Whereas, enormous teachers also indicated difficulties related to supra-segmental aspects. Intonation was reported as a common problem $(n=46)$. Thirty-two and thirty-three teachers listed rhythm and stress respectively as troublesome aspects in learning pronunciation. Syllable and vowel sounds were mentioned as the least prevalent problems $(\mathrm{n}=25)$.

\subsection{Teachers' practices of teaching pronunciation}

\subsubsection{Findings from the questionnaires}

The teachers' responses to the question that asked about the frequency of teaching pronunciation on a five-point scale were extremely positive: $27.1 \%$ said they always taught pronunciation in the classroom, and up to $51.4 \%$ said they taught it often ( $\mathrm{n}=36) ; 20 \%$ answered "sometimes" and only $1.4 \%$ said they rarely taught pronunciation $(n=1)$. None of the participants responded they never delivered a lecture on pronunciation $(\mathrm{n}=0)$.

\section{Teachers' practices in relation to general approaches of teaching pronunciation}

The five following statements present the primary approaches applied by the participants in teaching pronunciation. The positive results are shown in Figure 1.

Figure 1 shows that about half of the teachers $(57.1 \%)$ reported their integration of pronunciation teaching into their classes with specific focus of providing learners with feedback on mispronunciations. Furthermore, frequently using extra resources to teach explicit pronunciation were less popular approaches. They rarely applied teaching pronunciation as of $15.7 \%$ and $21.4 \%$ respectively. Three teachers $(4.3 \%)$ responded that they never taught pronunciation explicitly in their classes.

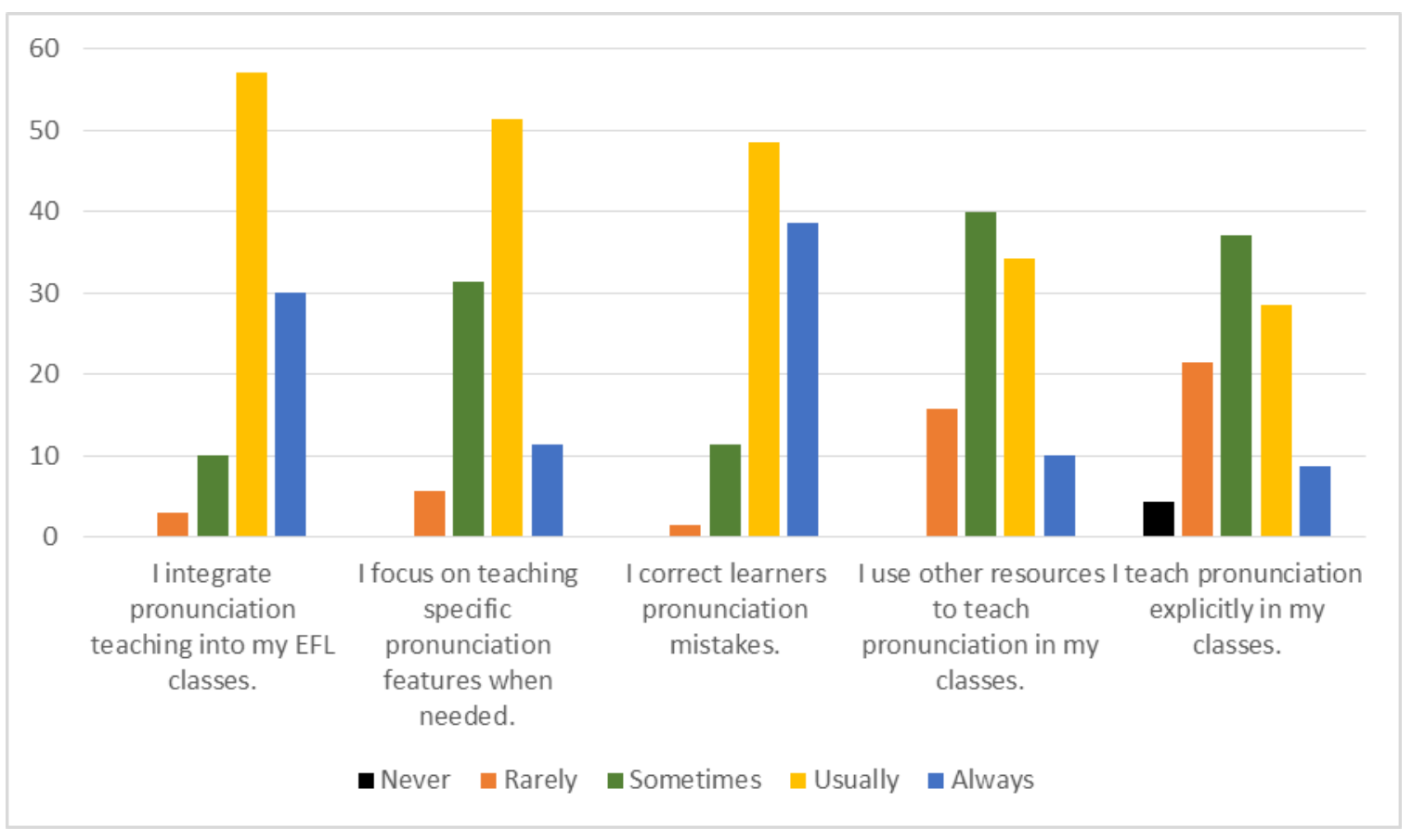

Figure 1. Main approaches to pronunciation teaching 
Teachers' practices with regard to pronunciation features

The following table informed the percentages of teachers' responses for each item in teachers' practices about features taught of teaching pronunciation.

Table 4 presents the majority of frequency was suffixes such as $-e d$ and $-s$ endings. $82.9 \%$ of the participants indicated that they often and always taught pronunciation. The second most frequently taught features were word stress $(78.6 \%)$, followed by problematic sounds which was often and always worked by $65.7 \%$ of the teachers. Additionally, utterance stress and intonation were commonly prevalent features taught by $62.9 \%$ and $58.5 \%$ of the teachers respectively. Approximately half of those who sometimes taught syllabus structures $(52.9 \%)$ and silent letters $(45.7 \%)$. Whereas, the two features never and rarely worked were weak forms (30\%) and schwa (25.7\%). Other aspects and detailed information are shown in Table 4.

Table 4. Percentages of teachers' practices of pronunciation features

\begin{tabular}{|c|c|c|c|c|c|c|c|c|c|}
\hline & \multirow[b]{2}{*}{ Items } & \multicolumn{2}{|c|}{$\begin{array}{l}\text { Never \& } \\
\text { Rarely }\end{array}$} & \multicolumn{2}{|c|}{ Sometimes } & \multicolumn{2}{|c|}{$\begin{array}{l}\text { Usually \& } \\
\text { Always }\end{array}$} & \multirow[t]{2}{*}{ Mean } & \multirow[t]{2}{*}{ SD } \\
\hline & & $\mathrm{F}$ & $\mathrm{P}(\%)$ & $\mathrm{F}$ & $\mathrm{P}(\%)$ & $\mathrm{F}$ & $\mathrm{P}(\%)$ & & \\
\hline 1 & Problematic sounds: e.g. th sounds $(/ \theta /$ and $/ \delta /)$ & 4 & 5.7 & 20 & 28.6 & 46 & 65.7 & 3.77 & .80 \\
\hline 2 & $\begin{array}{l}\text { Suffixes (-ed, -s ) e.g. the -ed endings (visited, } \\
\text { stayed, watched); the }- \text { s endings (tomatoes, } \\
\text { bats, computers) }\end{array}$ & 0 & 0 & 12 & 17.1 & 58 & 82.9 & 4.06 & .74 \\
\hline 3 & $\begin{array}{l}\text { Word stress :e.g. perfect= PERfect, eleven = } \\
\text { eLEven }\end{array}$ & 1 & 1.4 & 14 & 20 & 55 & 78.6 & 3.44 & .85 \\
\hline 4 & $\begin{array}{l}\text { Syllable structures: e.g. pencil has two } \\
\text { syllables : /pensl/ }\end{array}$ & 6 & 8.6 & 37 & 52.9 & 27 & 38.6 & 3.44 & .86 \\
\hline 5 & Silent letters: e.g. knife, exhibition & 8 & 11.4 & 32 & 45.7 & 30 & 42.9 & 3.21 & .85 \\
\hline 6 & $\begin{array}{l}\text { Minimal pairs: e.g. cut and cat, not and note, } \\
\text { ball and tall }\end{array}$ & 15 & 21.4 & 29 & 41.4 & 26 & 37.1 & 3.54 & .88 \\
\hline 7 & $\begin{array}{l}\text { Connected speech: e.g. Look it sounds like } \\
\text { loo.kit, short time sounds like shortime. }\end{array}$ & 9 & 12.9 & 23 & 32.9 & 38 & 54.3 & 3.21 & .82 \\
\hline 8 & $\begin{array}{l}\text { Accents: Differences between English accents } \\
\text { (e.g. British English and American English) }\end{array}$ & 14 & 20 & 30 & 42.9 & 26 & 37.2 & 3.67 & .96 \\
\hline 9 & $\begin{array}{l}\text { Intonation: e.g. I have a new house (falling } \\
\text { intonation) and I have a new house? (rising } \\
\text { intonation) }\end{array}$ & 9 & 12.9 & 20 & 28.6 & 41 & 58.5 & 3.70 & .77 \\
\hline 10 & $\begin{array}{l}\text { Utterance stress: stress placement on certain } \\
\text { words in utterances (e.g. I want that APPLE or } \\
\text { I want THAT bag) }\end{array}$ & 4 & 5.7 & 22 & 31.4 & 44 & 62.9 & 3.01 & .89 \\
\hline 11 & Schwa: /ə/: e.g. the sound in again and support & 21 & 30 & 27 & 38.6 & 22 & 31.5 & 3.14 & .87 \\
\hline 12 & $\begin{array}{l}\text { Weak forms: e.g. in I want a banana the word } \\
\text { "a" is less strong than the other words. }\end{array}$ & 18 & 25.7 & 28 & 40 & 24 & 34.3 & 4.37 & .89 \\
\hline 13 & $\begin{array}{l}\text { Stress-timed rhythm: e.g. CAT, EAT, FISH } \\
\text { takes roughly the same time to say as the } \\
\text { CATS will EAT the FISH. }\end{array}$ & 10 & 14.3 & 30 & 42.9 & 30 & 42.9 & 4.21 & .72 \\
\hline
\end{tabular}




\section{Teachers' practices concerning to activities used of teaching pronunciation}

The mean score of teachers' practices of activities $(M=$ $3.30, S D=.47)$ was at low level. A One Sample t-Test was conducted to examine whether they are statistically different. The result illustrates a statistically significant difference $(t=2.98, d f=69, p=.00<.05)$. Hence, the mean score of teachers' practices regarding activities was at high frequency.

Table 5 shows the detailed results in regard to activities used in teaching pronunciation

Reading aloud was the most popular strategy often or sometimes used by most of the teachers $(n=69)$. The second common activity used by $95.7 \% \quad(n=67)$ was classroom games. Repetition and imitation were the top prevalent activity $(n=66)$. Other practices often or sometimes used by most teachers were minimal pair drills and role play $(88.6 \%)$, marking words or sentences $(84.3 \%)$, reinforcement $(81.5 \%)$, chanting and body movements $(77.2 \%)$, and interactive media $(75.7 \%)$. The least frequent techniques were visual aids and mirrors. Half of the teachers $(n=35)$ never or rarely employed visual aids. $44.3 \%$ of the teachers indicated that they never or hardly ever used mirrors to help learners observe themselves how to articulate words $(n=31)$.

Table 5. Percentages of teachers' practices in teaching pronunciation regarding activities used

\begin{tabular}{|c|c|c|c|c|c|c|c|c|}
\hline \multirow{2}{*}{ Items } & \multicolumn{2}{|c|}{ Never \& Rarely } & \multicolumn{2}{|c|}{ Sometimes } & \multicolumn{2}{|c|}{$\begin{array}{c}\text { Usually \& } \\
\text { Always }\end{array}$} & \multirow[t]{2}{*}{ Mean } & \multirow[t]{2}{*}{ SD } \\
\hline & $\mathbf{F}$ & $\mathbf{P}(\%)$ & $\mathbf{F}$ & $\mathbf{P}(\%)$ & $\mathbf{F}$ & $\mathbf{P}(\%)$ & & \\
\hline Minimal pair drills (e.g., chip/cheap, ship/sheep) & 8 & 11.4 & 40 & 57.2 & 22 & 31.4 & 3.20 & .63 \\
\hline $\begin{array}{l}\text { Repetition and imitation: e.g. learners listen to the } \\
\text { teacher or to a CD and repeat, trying to imitate as } \\
\text { closely as possible. }\end{array}$ & 4 & 5.7 & 7 & 10 & 59 & 84.3 & 4.00 & .74 \\
\hline $\begin{array}{l}\text { Recordings: Having learners record and listen to } \\
\text { their pronunciation }\end{array}$ & 28 & 40 & 23 & 32.9 & 19 & 27.1 & 2.70 & 1.05 \\
\hline $\begin{array}{l}\text { Chanting: e.g. using Jazz Chants to practice } \\
\text { rhythm. }\end{array}$ & 16 & 22.8 & 24 & 34.3 & 30 & 42.8 & 3.14 & .95 \\
\hline Reading aloud & 1 & 1.4 & 16 & 22.9 & 53 & 75.7 & 4.01 & .81 \\
\hline $\begin{array}{l}\text { Visual aids (e.g., vocal tract animated diagrams, } \\
\text { representation of how a sound is articulated) }\end{array}$ & 35 & 50 & 19 & 27.1 & 16 & 22.9 & 2.53 & 1.06 \\
\hline Phonetic alphabet & 23 & 32.9 & 23 & 32.9 & 24 & 34.3 & 3.03 & 1.15 \\
\hline $\begin{array}{l}\text { Marking (e.g., underline the stressed words or } \\
\text { draw intonation arrows in a passage of text) }\end{array}$ & 11 & 15.8 & 14 & 20 & 45 & 64.3 & 3.64 & 1.02 \\
\hline $\begin{array}{l}\text { Interactive media (e.g., online games, } \\
\text { pronunciation software) }\end{array}$ & 17 & 24.3 & 18 & 25.7 & 35 & 50 & 3.27 & 1.03 \\
\hline $\begin{array}{l}\text { Drama and role play (e.g., practicing and } \\
\text { performing dialogues in pairs or groups paying } \\
\text { special attention to pronunciation) }\end{array}$ & 8 & 11.5 & 31 & 44.3 & 31 & 44.3 & 3.39 & .87 \\
\hline $\begin{array}{l}\text { Tactile reinforcement (e.g., asking learners to } \\
\text { touch their throats while pronouncing voiced and } \\
\text { voiceless sounds) }\end{array}$ & 13 & 18.5 & 20 & 28.6 & 37 & 52.9 & 3.40 & 1.08 \\
\hline $\begin{array}{l}\text { Mirrors: Having learners observe their own } \\
\text { articulation in a mirror. }\end{array}$ & 31 & 44.3 & 23 & 32.9 & 16 & 22.8 & 2.60 & 1.08 \\
\hline Classroom games & 3 & 4.3 & 12 & 17.1 & 55 & 78.6 & 4.10 & .84 \\
\hline $\begin{array}{l}\text { Body movement: e.g. having learners step, clap } \\
\text { their hands, tap their fingers or nod their heads } \\
\text { according to stress and intonation patterns }\end{array}$ & 16 & 22.8 & 21 & 30 & 33 & 47.2 & 3.31 & 1.12 \\
\hline
\end{tabular}


Teachers'practices with regard to most effective activities in teaching pronunciation

The participants were asked to list the pronunciation activities that were beneficial in helping learners to improve their pronunciation. These activities could be grouped into three categories: explicit, less explicit and implicit pronunciation activities. These results are presented in Table 6.

Table 6. Most effective activities in pronunciation instruction

\begin{tabular}{clcc}
\hline & \multicolumn{1}{c}{ Effective activities } & F & $\begin{array}{c}\text { P } \\
(\%)\end{array}$ \\
\hline 1 & Using phonetic symbols & 28 & 40 \\
\hline 2 & Individual sound exercises & 22 & 31.4 \\
\hline 3 & Minimal pairs & 33 & 47.1 \\
\hline 4 & Stress placement activities & 42 & 60 \\
\hline 5 & Syllable structure activities & 24 & 34.4 \\
\hline 6 & Using mirrors & 16 & 22.9 \\
\hline 7 & Doing repetition & 65 & 92.9 \\
\hline 8 & Singing English songs & 30 & 42.9 \\
\hline 9 & Reading aloud & 51 & 72.9 \\
\hline 10 & Using games & 40 & 57.1 \\
\hline 11 & Watching English videos & 45 & 64.3 \\
\hline 12 & $\begin{array}{l}\text { Speaking to their classmates and to native } \\
\text { speakers }\end{array}$ & 60 & 85.7 \\
\hline 13 & Role play & 26 & 37.1 \\
\hline
\end{tabular}

Overall, it is interesting to note that the vast majority of teachers preferred less explicit pronunciation activities, such as doing repetition $(\mathrm{n}=65)$, reading aloud $(\mathrm{n}=51)$, and singing English songs $(\mathrm{n}=30)$. The teachers mentioned exclusively implicit activities: speaking to their classmates and to native teachers $(\mathrm{n}=60)$, watching English videos $(n=45)$, using games $(n=40)$ and role play $(n=26)$. Additionally, explicit pronunciation activities were reported with some variations. None of the respondents listed other effective pronunciation activities.

\subsection{Findings from observation}

Three themes are identified as teachers' main approaches, the focused lesson content and teachers' activities.

\subsubsection{Teachers' main approaches}

The following extract demonstrates general approaches were used in their classrooms which were intuitive-imitative, analytic-linguistic and integrative approach. For example:

"The teacher integrated pronunciation lessons in speaking and listening lessons. She focused on final sounds in a vocabulary part by emphasizing and repeating the words, then asked the learners to imitate. She showed the flashcard with the picture of the color "orange" and pointed at the flashcard, said "orange, orange, orange", "It's an orange orange". She focused on final sound $/ d z /$. Then the learners repeated the words and sentences after the teacher" (OB. Nguyen.6.04-6.06 p.m.).

Giang introduced new vocabularies (numbers) and incorporated pronunciation during the lesson. She asked the learners to repeat and correct mistakes if necessary. The following conversation is an example of that discourse.

" $T$ : Number... [The teacher showed the flashcard of number eleven]

Ss: eleven

T: good job, thank you!

Ss: eleven ...eleven.......... eleven, right.

T: and number....

Ss: twelve

$T:$ twelve.... tw...tw ....twelve ....v...v ..., twelve...[The teacher focused on $/ \mathrm{tw} /$ and $/ \mathrm{v} /$ ]

Ss: twelve.... twelve...

T: Number....

Ss: threeteen

T: oh no...

Ss: thirteen. Thirteen....th...th .... [The teacher emphasized on $/ \theta /]$

$T$ : and number....

Ss: fourteen

T: good job!

Ss: fourteen .... fourteen

T: Number....

Ss: fiveteen

T: fiveteen???

Ss: fifteen.

$T:$ fifteen .... fifteen ... $f . . . f \ldots f .$. fifteen $[$ The teacher focused on /f/]

Ss: fifteen

$T$ : and number....

Ss: sixteen

T: $\quad$ sixteen .......six.... $/ k s / \ldots . \quad$ six....../ks/.... Sixteen [The teacher focused on $/ \mathrm{ks} /$ ]

Ss: sixteen" [Learners practiced and imitated after the teacher's pronunciation] (OB.Giang.6.05-6.06 p.m.)

Besides the implicit way to teach pronunciation, the teacher also highlighted the phonetic alphabet with letter " $m$ " and " $n$ ". The practice was carried out in a form of oral drill where she presented the pronunciation of each word, focused on the sound $/ \mathrm{m} /$ and $/ \mathrm{n} /$ and the learners imitated after her. It was also observed that whenever the group reading aloud made any mistakes in pronunciation were corrected by the teacher. Cat repeated the word and her learners mimicked until they have pronounced the word correctly.

"T: letter....

Ss: $/ \mathrm{m} /$

T: sounds like....

Ss: $m \ldots \ldots$

$T: m \ldots \ldots . . . .$. 
Ss: $m \ldots \ldots . . . . \ldots \ldots . . . .$.

T: easy...letter....

Ss: $/ n /$

T: letter $/ n / \ldots . / n / \ldots$.

Ss: $/ n / \ldots \ldots \ldots / n / \ldots \ldots / n / \ldots$

$T: / m / \ldots / n / \ldots . / m / \ldots / n /$

Ss: $/ m / \ldots / n / \ldots \ldots / m / \ldots / n /$

$T: \because m \ldots \ldots n \ldots \ldots m \ldots \ldots n \ldots n \ldots \ldots m \ldots m \ldots . . . . . . . . . .$.

Ss: $m \ldots n \ldots m \ldots \ldots n \ldots m n \ldots \ldots m \ldots m \ldots m \ldots n \ldots n \ldots n \ldots$

[The teacher made a chant]

$T: m \ldots \ldots . n \ldots \ldots n \ldots . n \ldots \ldots n \ldots n$ [The learners tried to imitate]

Ss: $n \ldots \ldots . n$

$T: m \ldots \ldots . m \ldots . . . .$.

Ss: monkey

T: monkey.... monkey

Ss: monkey

$T: m \ldots m \ldots \ldots \ldots$

Ss: mouth

T: mouth.... mouth $/ \theta /$.... mouth / $\theta /$

Ss: mouth....mouth." (OB.Cat. 11.01-11.04 a.m.)

Other teacher explicitly taught pronunciation with a minimal pair initial / $/ \mathrm{k} /$ and $/ \mathrm{g} /$.

"The teacher wrote and read loud the letters $/ \mathrm{k} /$ and $/ \mathrm{g} /$ in front of the learners. The learners were asked to search for words which started with letters $/ \mathrm{k} /$ and $/ \mathrm{g} /$. Those words were imitated and practiced individually and chorally. She had conducted an exercise on discrimination of sounds $/ \mathrm{k} /$ and $/ \mathrm{g} /$ from the textbook. And the learners identified the sounds by circling or writing in their textbook. She also applied games to let the learners practice these sounds" (O.B. Nhi.15.19-15.35. p.m.)

\subsubsection{The focused areas in teaching pronunciation}

Table 7 indicates the content focus in the lesson observed of six teachers. The findings revealed that the vast majority of teachers paid attention to the segmental features more than the supra-segmental features.

Table 7 shows that most of the teachers preferred to teach segmental features in their lessons. Examples of these aspects are presented below:

"Giang reviewed the numbers (1-20) and wrote the numbers (30, 40, 50, 60, 70, 80, 90, 100) on the board. After that, she read aloud these numbers several times and distinguished the way to pronounce $(13 \& 30 ; 14$ \& 40; 15 \& 50). Specially, she exaggerated the long vowel sounds /i:/ of thirteen, fourteen and fifteen. The learners strived to remember and imitated afterwards." (O.B. Giang. 6.08-06.15 p.m.)

"Nguyen focused on the plural sounds $/ s /$ and /z/ in the structure "They are + colors + objects". For instance, "They are green crayons/ They are brown ants". Her focus on pronunciation content was on teaching the production of sounds $/ \mathrm{s} /$ and $/ z /$ in the sentence. She directly corrected the mistakes for each sentence if the learners mispronounced." (O.B. Nguyen. 6.20-6.27 p.m.)

On the other hand, two other teachers had tried to integrate both segmental and supra-segmental features in their lessons. The supra-segmental features as stress, rhythm and intonation were indirectly taught through speaking activities.

"Tam created the context to lead to the grammar point of modal verb for permission and obligation (must) mustn't; have to/don't have to). She emphasized on final sounds $/ \mathrm{t} / \mathrm{N} / \mathrm{V} /$ and also taught the learners the way to link the sound "have to" to /hoefto/. The learners had practiced in advance and presented in front of the class with the context. She asked the learners to focus on intonation for raising the wh-questions or yes/no questions.” (O.B. Tam. 3.03-3.27 p.m.)

"Loc asked the learner to show the cardinal directions by giving the picture. Any mistakes were noted and she gave feedback later. For example, she asked "Can you pronounce the word "south" again?" because the learner did not focus on the sound / $\theta /$. She also wrote the sentence "Sanghai is in the east of China." and drew the line to link "is in" and "east of". The learners were asked to practice several times." (O.B. Loc. 6.43-6.55 p.m.)

Table 7. Focused areas in the teaching of pronunciation

\begin{tabular}{|c|c|c|c|c|c|c|c|}
\hline & Tam & Nhi & Loc & Giang & Nguyen & Cat \\
\hline & Sound discrimination (vowels and consonants) & $\checkmark$ & $\checkmark$ & $\checkmark$ & $\checkmark$ & $\checkmark$ & $\checkmark$ \\
\hline & Consonant clusters in different combinations & $\checkmark$ & $\checkmark$ & $\checkmark$ & $\checkmark$ & $\checkmark$ & $\checkmark$ \\
\hline & Past tense and plural forms & $\checkmark$ & $\checkmark$ & & $\checkmark$ & $\checkmark$ & \\
\hline & Sentence stress and intonation & $\checkmark$ & & $\checkmark$ & & & \\
\hline
\end{tabular}




\subsubsection{Teachers' activities}

The activities teachers used to help learners practice pronunciation include spelling the words, conducting error correction, playing games, reading aloud, role play, and using tongue twisters, as shown in the following scenarios.

"S1: Hey... Would you like to hang out today?

S2: uhm.... I would love, that, but.... I have to stay at home to do the household chores. [The teacher asked the learners to practice like "hafta"]

S1: What do you have to do?

S2: I have to clean my room, wash the dishes, take out the garbage and sweep the floor.

S1: Oh... Do you have to clean the toilet? I hate it.

S2: I hate it too. I don't have to do that because my mom does it.

S1: Sounds good!

S2: Yeah...... "(O.B. Tam. 3.18-3.27 p.m.)

"Nhi used tongue twisters to teach pronunciation. She wrote "A good cook could cook as much cookies as a good cook who could cook cookies", and "Get the glass with the green grapes" on the board. After that she said out loud as a sample, then asked them to mimic as follow and played with the words." (O.B. Nhi 15.36-15.45 p.m.)

"T: Ok.. What color is it? [The teacher showed the flashcard of yellow]

Ss: yellow

T: yellow... again

Ss: Yellow

T: This one?

Ss: black

T: Again ......black..........k... [The teacher focused on a sound $/ k /]$

Ss: black.

$T: / k / \ldots . . / k / \ldots . . / k /$

Ss: Black.../k/

T: How about this one?

Ss: Green....

$T: G \ldots G \ldots G \ldots G r \ldots . . . G r \ldots$. Green

Ss: G.... Green [The learners pronounced without the sound $/ r /]$

$T: G \ldots . r \ldots \ldots . G \ldots . . . . . G r \ldots$. Green [The teacher emphasized the cluster sounds /gr/]

Ss: Green.

T: And...?

Ss: White

$T: / t / \ldots . / t / \ldots . . / t / \ldots . .$. White [The teacher focused on the sound $/ t /]$

Ss: White." (O.B. Nguyen. 6.08-6.13 p.m.)

\section{Discussion}

The findings from the current study indicate that teachers held strong beliefs about the value of teaching pronunciation in English classes at foreign language centers. However, their self-reports reveal that they tended to correct learners' mispronounced words. This positive influence is in line with several studies on pronunciation teaching practices (e.g., [33]). However, as noted in the literature [28], evidence shows that frequently correcting mispronounciations for Brazilians were less prevalent approach. The most preferred and effective activities are repitition, read aloud and classroom games while body movement, mirrors, pronunciation visual aids and recordings are never or rarely used. These findings are in agreement with several studies in the literature [22] and [8] findings which show the favored traditional activities were repetition and read aloud. It can be inferred that teachers were insufficient professional knowledge in teaching pronunciation. One more explanation for favoring in traditional activities is perhaps contextual factors such as time constraints, insufficient teaching and learning resources.

Moreover, the participants' beliefs and practices mostly concentrate on segmental features and thus, this tendency explains the challenges teachers encountered while teaching supra-segmental features. The teachers tended to focus on the most challenging features such as the problematic sounds $/ \theta /$ and $/ ð /(80 \%)$ and suffixes sounds "-ed" and "s" 67.1\%). Despite the difficult supra-segmental features experienced by the learners were mentioned like stress $(47.1 \%)$, rhythm $(45.7 \%)$ and intonation $(65.7 \%)$, they were neglected in the classrooms. The findings concur with [43]; [31]; [32]; [42], indicating this focus on the features found challenging by learners. First, pronunciation was incorporated with other skills, so the teacher would correct pronunciation mistakes made by learners. Second, it could be attributed to the inadequate professional training because of teachers' awareness and knowledge of pronunciation regarding phonetics course at university. As a result of a lack of professional pronunciation training courses, teachers found the need for more training opportunities in pronunciation, which aligns with previous studies [28]; [32]; [29] and [30].

The majority of teachers indicated that intelligibility is a better goal for teaching pronunciation than a nativeness target which is widely supported by scholars of the field such as [30]; [28]; [49] and [12]. They stated that pronunciation teaching could be handled by non-native English speakers. This result may be explained by the fact that most of the participants could not speak like native speakers, and their learners did not live and work in English speaking countries which presents a challenge to achieve the nativeness target. Another explanation for this is that the school did not put much pressure for teachers to obtain the native-like proficiency. Therefore, the purpose of teaching pronunciation is to help learners communicate intelligibly and fluently.

\section{Conclusions}

The purpose of the current study was to examine 
teachers' beliefs and practices of teaching pronunciation in a Vietnamese context. The findings from this investigation show that teachers had positive beliefs about pronunciation instruction and that they were observed to integrate pronunciation into their lessons together with other English skills. Most of the teachers reported that intelligibility was their goal and the focus on segmental features took precedence over in teaching pronunciation aspects. Moreover, the teachers seemed to employ traditional approaches and activities due to the lack of professional knowledge in pronunciation pedagogy. Repetition, read aloud and classroom games were their preferred activities. Time constraints, learners' English language proficiency, syllabus requirements and examination-focused format, insufficient pronunciation knowledge and learning resources should be considered. Although the current study is based on a small sample of participants, the findings provide other teachers with insights into how to tailor their pronunciation instruction and maximize learners' pronunciation learning in the long run.

\section{About the Authors}

Tran Thi Diem Phuong teaches English at a foreign language center in Can Tho City, Vietnam. She earned an MA in Principles and Methods in English Language Education, School of Foreign Languages, Can Tho University, Vietnam. Her research interests include pronunciation and communicative language teaching and learning aspects.

Nguyen Вии Huan is senior lecturer in English, School of Foreign Languages, Can Tho University, Vietnam. His doctoral study focuses on teacher beliefs and changes in science education at tertiary contexts. His research interests include teacher beliefs, teacher change, ESP, and curriculum planning. He is now involved in writing teaching materials for both EFL and ESP students at the university.

\section{REFERENCES}

[1] B. Seidlhofer, "Pronunciation," in The Cambridge Guide to Teaching English to Speakers of Other Languages, Cambridge, 2001, pp. 56-65.

[2] C. T. Ha, "Common pronunciation problems of Vietnamese learners of English," Journal of Science, vol. 21, no. 1, pp. 35-46, 2005.

[3] H. B. H. P. \&. H. S. Nguyen, "Challenging ESP teacher beliefs about active learning in a Vietnamese university," Teacher Development, vol. 23, no. 3, pp. 345-365, 2019.

[4] H. B. Nguyen, "Beliefs about support for teacher change in English for specific purposes university classes," New Zealand Studies in Applied Linguistics, vol. 19, no. 2, pp.
36-48, 2013.

[5] V. Cook, Second language learning and language teaching (4th ed.), London: Hodder Education, 2008.

[6] L. \&. Z. B. Yate, Give it a go: Teaching pronunciation to adults, AMEP Research Centre, Department of Immigration and Citizenship, Macquarie University, Sydney, Australia, 2009.

[7] A. Gilakjani, "What factors influence the English pronunciation of EFL learners?," Modern Journal of Language Teaching Methods, vol. 6, no. 2, pp. 314-326, 2012.

[8] A. \&. M. J. Baker, "Knowledge base of pronunciation teaching:Staking out the territory," TESL Canada Journal, vol. 28, no. 2, pp. 29-50, 2011.

[9] A. Baker, "Exploring teachers' knowledge of second language pronunciation techniques: Teacher cognitions, observed classroom practices, and student perceptions," TESOL Quarterly , vol. 48, no. 1, pp. 136-163, 2014.

[10] R. I. \&. D. T. M. Thomson, "The effectiveness of L2 pronunciation instruction: A narrative review," Applied Linguistics, vol. 36, no. 3, pp. 326-344, 2015.

[11] L. \&. S. C. Henrichsen, "Advanced adult EFL students' perspectives on the benefits of pronunciation instruction," in Proceedings of the 6th Pronunciation in Second Language Learning and Teaching Conference (ISSN 2380-9566), Santa Barbara, CA, 2016, pp. 197-205.

[12] J. M. Levis, "Changing context and shifting paradigms in pronunciation teaching," TESOL Quarterly, vol. 39, no. 3, pp. 369-377, 2005.

[13] T. M. \&. M. M. J. Derwing, "Second language accent and pronunciation teaching: A research-based approach," TESOL Quarterly, vol. 39, no. 3, pp. 379-397, 2005.

[14] P. \&. I. T. Trofimovich, "Disentangling accent from comprehensibility," Bilingualism: Language and Cognition, vol. 15, no. 4, pp. 905-916, 2012.

[15] I. Timmis, "Native-speaker norms and international English: A classroom view," ELT Journal, vol. 56, no. 3, pp. 240-249, 2002.

[16] K. \&. W. R. Keys, "Ten questions on the phonology of English as an international language," ELT Journal, vol. 56, no. 3, pp. 298-302, 2002.

[17] S. Loewen, Introduction to Instructed Second Language Aquisition, New York: NY: Routledge, 2020.

[18] S. Thornbury, CELTA, Cambridge: Cambridge University Press, 2008.

[19] E. Tergujeff, "Learner perspective on English pronunciation teaching in an EFL context," Research in Language, vol. 11, no. 1, pp. 81-95, 2013.

[20] A. \&. B. M. Baker, "Feedback on second language pronunciation: A case study of EAP teachers' beliefs and practices," Australian Journal of Teacher Education, vol. 28, no. 2 , pp. 29-50, 2016.

[21] M. B. D. M. \&. G. J. M. Cele-Murica, Teaching Pronunciation, Cambrdge University Press, 1996. 
[22] M. \&. H. S. Hismanoglu, "Language teachers' preferences of pronunciation teaching techniques: Traditional or modern?," Procedia - Social and Behavioral Sciences, vol. 2, no. 2, pp. 983-989, 2010.

[23] S. T. Lee, "Teaching pronunciation of English using computer assisted learning software: An action research study in an institute of technology in Taiwan," Doctoral dissertation, Australian Catholic University, 2008.

[24] J. \&. S. S. Burgess, "Phonology and pronunciationin integrated language teaching and teacher education," System, vol. 28, no. 5, pp. 191-215, 2000.

[25] B. Chela-Flores, "Pronuncaition and language learning: An integrative approach," International Review of Applied Linguistic in Language Teaching, vol. 39, no. 2, pp. 85-101, 2001.

[26] R. G. Muir-Herzig, "Technology and its impact in the classroom," Computers and Education, vol. 42, no. 2, pp. 111-131, 2004.

[27] S. Macdonald, "Pronunciation - views and practices of reluctant teachers," Prospect: An Australian Journal of TESOL, vol. 17, no. 3, pp. 3-18, 2002.

[28] L. Buss, "Beliefs and practices of Brazilian EFL teachers regarding pronunciation," Language Teaching Research, vol. 20, no. 5, pp. 619-637, 2016.

[29] A. Huensch, "Pronunciation in foreign language classroom: Instructors' training, classroom practices, and beliefs," Language Teaching Research, vol. 23, no. 6, pp. 745-764, 2019.

[30] B. \&. Y. R. Bai, "EFL teachers' beliefs and practices about pronunciation teaching," ELT Journal, vol. 73, no. 2, pp. 134-143, 2019.

[31] H. W. Chiu, "Practical understandings: Teachers' beliefs and practcies in pronunciation teaching".

[32] L. T. \&. N. J. Nguyen, "Pronunciation teaching in tertiary EFL classes: Vietnameses teachers' beliefs and practcies," TESL-EJ, vol. 24, no. 1, pp. 1-20, 2020.

[33] J. A. H. A. K. \&. D. T. M. Foote, "Articles survey of the teaching of pronunciation in adult ESL programs in Canada, 2010," TESL Canada Journal, vol. 29, no. 1, pp. 1-22, 2011.

[34] S. Borg, "The impact of in-service teacher education on language teachers' beliefs," System, vol. 39, no. 3, pp. 370-380, 2011.

[35] E. Alijanian, "An investigation of Iranian EFL teachers' beliefs about grammar," Journal of Educational and Scocial Research, vol. 2, no. 3, pp. 335-340, 2012.

[36] S. \&. B. S. Phipps, "Exploring tensions between teachers' grammar teaching beliefs and practices," System, vol. 37, no. 3, pp. 380-390, 2009.

[37] I. Kuzborska, "Links between teachers' beliefs and practices and research on reading," Reading in a Foreign Language , vol. 23, no. 1, pp. 102-128, 2011.

[38] M. N. \&. N. M. Karimi, "The congruity / incongruity of EFL teachers' beliefs about listening instruction and their listening instruction and their listening instructional practices," Australian Journal of Teacher Education, vol. 42, no. 2, pp. 62-80, 2017.

[39] M. S. H. \&. A. M. Yunus, "EFL teachers' cognition of teaching English pronunciation techniques: A mixed-method approach," English Language Teaching, vol. 9, no. 2, pp. 20-42, 2016.

[40] N. C. \&. S. A. M. Sifakis, "Pronuncaition issues and EIL pedagogy in the periphery: A survey of Greek state school teachers' beliefs," TESOL Quarterly, vol. 39, no. 3, pp. 467-488, 2005.

[41] A. F. D. T. E. K. A. M. D. K.-N. A. W.-K. E. L. D. C. U. \&. C. L. Henderson, "The English pronunciation teaching in Europe survey: Selected results.," Research in Language, vol. 10, no. 1, pp. 5-27, 2012.

[42] O. Yagiz, "EFL language teachers' cognitions and observed classroom practices about L2 pronuncaition: The context of Turkey," Novitas ROYAL (Research on Youth and Language), vol. 12, no. 2, pp. 187-204, 2018.

[43] M. \&. A. G. Alsofyani, "Exploring EFL teachers' beliefs and practices regarding pronunciation teaching in a Saudi setting," Arab World English Journal (AWEJ), vol. 8, no. 4, pp. 384-400, 2017

[44] G. P. Georgiou, "EFL teachers' cognitions about pronunciation in Cyprus," Journal of Multilingual and Multicultural Development, vol. 40, no. 6, pp. 538-550, 2019.

[45] Y. \&. S. J. Uchida, "A survey of pronuncaition instruction by Japanese teacher of English: Phonetic knowledge and teaching practice," Journal of the Tokyo University of Marine Science and Technology, vol. 14, no. 1, pp. 65-75, 2018.

[46] A. Bryman, "Integrating quantitative and qualitative research: How is it done?," Qualitative Research, vol. 6, no. 1, pp. 97-113, 2006.

[47] M. F. Pajares, "Teacher's beliefs and educational research: Cleaning up a messy construct," Review of Educational Reasearch, vol. 62, no. 3, pp. 307-332, 1992.

[48] J. Cohen, "Quantitative methods in psychology: A power primer," Psychological Bulletin, vol. 112, no. 1, pp. 155-159, 1992.

[49] G. Couper, "Teacher cognition of pronunciation teaching amongst English language teachers in Uruguay," Journal of Second Language Pronunciation, vol. 2, no. 1, pp. 29-55, 2016.

[50] E. Alijanian, "An investigation of Iranian EFL teachers' beliefs about grammar," Journal of Educational and Social Research, vol. 2, no. 3, pp. 335-340, 2012.

[51] S. Canagarajah, "Editor's note," TESOL Quarterly, vol. 39, no. 3, pp. 365-366, 2005.

[52] M. Hismanoglu, "Current perspectives on pronunciation learning and teaching," Journal of Language and Linguistic Studies, vol. 2, no. 1, pp. 101-110, 2006.

[53] H. Fraser, Coordinationg improvements in pronunciation teaching for adult learners of English as a second language, University of New England, Armidale, NSW, 2000. 